\title{
SISTEM KONTROL OPTIMAL PADA KONTROL POSISI MOTOR DC
}

\author{
Asnil $^{(1)}$, Irma Husnaini ${ }^{(2)}$ \\ ${ }^{(1)(2)}$ Dosen Jurusan Teknik Elektro, Fakultas Teknik Universitas Negeri Padang
}

\begin{abstract}
Abstrak
Pengaturan posisi motor DC menggunakan kontrol optimal dengan metode LQR untuk melihat performansi yang berkaitan dengan kestabilan dan kecepatan respon sistem dilakukan dengan membandingkan control PID dan LQR dalam keadaan gangguan dan tanpa gangguan. Posisi referensi plant yang diberikan sebesar $11^{0}$ dan $60^{\circ}$. Hasil pengujian saat adanya gangguan memperlihatkan kontroler PID dan LQR memiliki performansi yang baik dengan settling time masing-masing $\mathrm{t}=0.72$ detik dan $\mathrm{t}=0.48$ detik. Saat adanya gangguan, waktu yang dibutuhkan sistem dengan LQR untuk mencapai kestabilan sama dengan keadaan tanpa gangguan yaitu 0.48 detik, sedangkan nilai persentase overshoot berturut-turut $0.384 \%$ dan $0.599 \%$ untuk posisi $11^{\circ}$ dan $60^{\circ}$. Pada kontroler PID, peningkatan gangguan menyebabkan meningkatnya nilai overshoot, gangguan $0.5 \mathrm{Nm}$ menyebabkan overshoot berturut-turut $69,4 \%$ dan $28.9 \%$ untuk posisi $11^{\circ}$ dan $60^{\circ}$ dengan waktu settling maing-masing 1.0 detik dan 0.86 detik. Hasil pengujian model plant motor DC memperlihatkan LQR lebih responsif terhadap gangguan dibandingkan kontroler PID.
\end{abstract}

Kata kunci : Kontrol optimal , Performansi , LQR, Kestabilan, Motor DC 


\section{Pendahuluan \\ I.1. Latar belakang masalah}

Sistem kendali telah memegang peranan yang sangat penting dalam kehidupan sehari-hari. Sistem kendali yang semakin berkembang dapat meningkatkan kinerja sistem, kualitas produksi dan menekan biaya produksi. Keberadaan kontroler dalam sebuah sistem kontrol mempunyai kontribusi yang besar terhadap prilaku sistem. Pada prinsipnya hal itu disebabkan oleh tidak dapat diubahnya komponen penyusun sistem tersebut. Artinya, karakteristik plant harus diterima sebagaimana adanya, sehingga perubahan perilaku sistem hanya dapat dilakukan melalui penambahan suatu sub sistem, yaitu kontroler. Masalah umum dalam sistem kontrol adalah pencapaian spesifikasi performansi yang berkaitan dengan kestabilan dan kecepatan respon sehingga akan menghasilkan sistem kontrol yang optimal. Hal lain yang juga perlu diperhatikan adalah bagaimana spesifikasi performansi tersebut dapat dicapai.

Beberapa tahun terakhir ini, telah banyak usaha yang dilakukan untuk pengembangan metode kontroler terutama di dunia industri yang disebut metode kontrol modern . Metode dan teori kontrol automatik konvensional sudah lama berkembang sejak pertengahan abad 19. Metode Tempat Kedudukan Akar, Nyquist, diagram Bode dan sebagainya adalah beberapa metode yang menggunakan kawasan frekuensi sebagai domain pembahasan yang telah memberikan sumbangan berarti, khususnya untuk sistem sederhana.Semua metode di atas digunakan untuk sistem linier dan tidak berubah waktu (misalnya sistem kontrol PID), akan tetapi jika sistem tidak linier atau linier tetapi berubah waktu dan sistem dengan multi input-multi output maka kriteria kestabilan sedemikian tidak berlaku (Ogata, K, 1997).

Perkembangan selanjutnya untuk sistem yang memerlukan perhitungan real time dan kualitas output dengan indeks performansi maka berkembang metode sistem kontrol diantaranya adalah sistem kontrol optimal .
Diantara keuntungan dari sistem kontrol optimal adalah prosedur perancangan dapat dipakai untuk sistem-sistem linier yang berubah terhadap waktu, serta sistem yang dirancang tidak hanya stabil tetapi juga menjadikan sistem kontrol yang optimal

Sistem Kontrol Optimal adalah konsep optimasi sistem kontrol yang memperhitungkan pemilihan indeks atau kriteria performansi serta desain yang akan menghasilkan sistem kontrol optimal dalam batas-batas kendala fisik. Indeks performansi didefinisikan sebagai suatu fungsi yang harganya menunjukan seberapa baik performansi sistem yang sebenarnya mendekati performansi yang diinginkan. Pada sebagaian kasus praktis perilaku sistem dioptimalkan dengan memilih vektor kontrol sedemikian rupa sehingga indeks performansi diminimumkan dan atau dimaksimumkan. Secara garis besar teori kontrol optimal adalah suatu teori kontrol yang pencarian solusinya didasarkan pada usaha untuk meminimumkan atau memaksimalkan suatu fungsi indeks kinerja. Fungsi ini terdiri dari beberapa buah variabel sistem yang diminimasi harganya dengan memberikan matrik bobot yang menyatakan besarnya pembobotan untuk masing-masing variabel sistem tersebut (Saiful Manan) .

Linier Quadratic Regulator (LQR) merupkan bentuk khusus sistem kontrol optimal. Pada sistem pengaturan posisi dituntut ketelitian yang tinggi dan respon waktu yang baik, sedang sistem kontrol optimal diharapkan memenuhi fungsi indeks kinerja yang diinginkan. Kontrol optimal dengan menggunakan metode LQR pada penelitian ini digunakan untuk mengatur posisi motor dc, diharapkan posisi sudut keluaran $\theta$ o mengikuti setiap perubahan sudut masuk $\theta \mathrm{i}$ yang diberikan pada saat tanpa adanya gangguan dan dengan adanya gangguan serta sistem tidak hanya menjadi stabil tetapi juga menjadikan sistem kontrol yang optimal. 


\section{I.2. Maksud dan Tujuan}

Tujuan penelitian ini adalah membandingkan kinerja kontrol optimal menggunakan metode PID dan LQR untuk pengontrolan posisi motor $\mathrm{dc}$ dengan memberikan perubahan masukan posisi dan melihat pengaruhnya terhadap keluaran yang diinginkan serta performansi yang berkaitan dengan kestabilan sistem, sehingga terpenuhinya kebutuhan sistem yang stabil untuk setiap perubahan posisi motor dc. Secara khusus, tujuan penelitian ini adalah:

\section{I.3. Tinjauan Pustaka}

\section{I.3.1. Model Matematis untuk Motor DC}

Motor DC mempunyai medan eksitasi yang terpisah sehingga pengontrolan motor dc dapat dibedakan, motor dc arus medan tetap dengan pengontrolan arus jangkar dan motor dc arus jangkar tetap dengan pengontrolan arus medan. Pengontrolan arus medan penguatan yang dibutuhkan dapat disederhanakan karena kebutuhan daya yang rendah. Namun menyediakan arus yang konstan jauh lebih sulit dalam pengontrolan medan dengan beban motor yang selalu berubah. Sedang pada pengontrolan arus jangkar gaya gerak listrik balik bekerja sebagai redaman dan pada pengontrolan arus medan tidak ada sehingga untuk redaman diperlukan, harus diberikan oleh motor dan beban. Selain itu kontrol arus medan mempunyai efisiensi yang rendah dan energi panas yang terjadi pada jangkar menimbulkan persoalan tersendiri. Konstanta waktu motor dc dengan penngontrolan medan biasanya lebih besar dari konstanta waktu motor dc pengaturan arus jangkar yang sebanding. Meskipun demikian dalam membandingkan konstanta waktu antara operasi dengan pengontrolan arus medan dan pengontrolan arus jangkar harus mempertimbangkan konstanta waktu penguat daya dalam studi operasi pengontrolan jangkar sehingga dalam penerapan sistem kotrol optimal indeks kinerja linear kuadratik ini digunakan motor DC pengontrolan arus jangkar.
Motor DC dengan pengontrolan jangkar menggunakan medan magnet permanen yang tetap. Gambar berikut ini adalah pemodelan dengan rangkaian listrik dari motor DC pengontrolan jangkar dan diagram fisiknya.

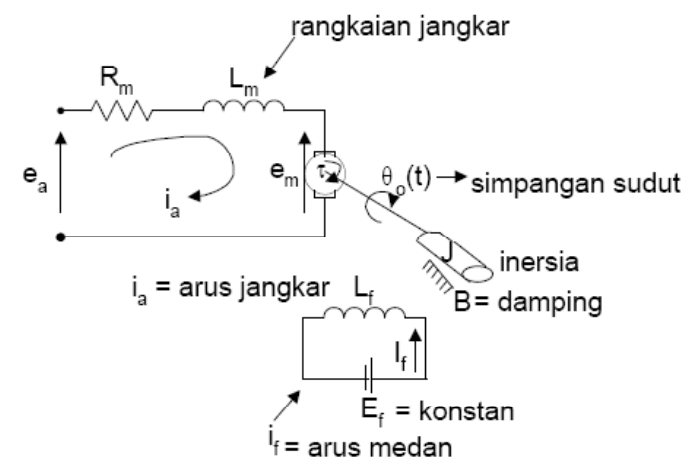

Gambar 1. Motor DC dengan Pengontrolan Arus Jangkar (phillips, 1998)

Pada gambar ini dimana :

$$
\begin{aligned}
& \mathrm{e}_{\mathrm{a}}=\text { tegangan jangkar } \\
& \mathrm{R}_{\mathrm{m}}=\text { tahanan jangkar } \\
& \mathrm{L}_{\mathrm{m}}=\text { induktansi jnagkar } \\
& \mathrm{e}_{\mathrm{m}}=\text { tegangan EMF-balik } \\
& \mathrm{i}_{\mathrm{f}}=\text { arus medan (konstan) } \\
& =\text { fluks (konstan) medan } \\
& \dot{\theta}_{0}=\text { sudut poros motor } \\
& \mathrm{K}=\text { konstanta motor } \\
& \mathrm{T}=\text { torsi yang dibangkitkan oleh } \\
& \text { poros } \\
& \mathrm{J}=\text { momen inersia }
\end{aligned}
$$

Torsi motor $T$, dihubungkan dengan arus jangkar $i_{\mathrm{a}}$, oleh faktor pengali $\mathrm{K}_{\mathrm{i}}$. Sedangkan gaya gerak listrik balik $\mathrm{e}_{\mathrm{m}}$, dihubungkan dengan kecepatan sudut melalui persamaan berikut :

$$
e_{m}(t)=K \phi \frac{d \theta_{0}}{d t}
$$

Kita asumsikan bahwa fluks $\phi$ konstan, sehingga

$$
\begin{aligned}
& e_{m}(t)=K_{m} \frac{d \theta_{0}}{d t} \\
& T(t)=K_{m} . i_{a} \phi(t)
\end{aligned}
$$




$$
T(t)=K_{i} \cdot i_{a}(t)
$$

Dari gambar 1, dapat kita turunkan persamaan motor berdasarkan Hukum Newton dan Kirchoff

$$
\begin{gathered}
J \frac{d^{2} \theta(t)}{d t^{2}}+B \frac{d \theta(t)}{d t}=K_{t} \cdot i_{a} \\
L_{m} \frac{d i_{a}(t)}{d t}+R_{m} \cdot i_{a}(t)=e_{a}(t)-e_{m}(t) \\
L_{m} \frac{d i_{a}(t)}{d t}+R_{m} \cdot i_{a}(t)=e_{a}-K_{m} \cdot \dot{\theta}
\end{gathered}
$$

Gunakan transformasi Laplace, maka persamaan diatas dapat ditulis sebagai:

$$
\begin{gathered}
\left(J s^{2}+B s\right) \theta(s)=K_{t} \cdot I_{a}(s) \\
\left(L s+R_{a}\right) I_{a}(s)=E_{a}(s)-K_{t} s \theta(s)
\end{gathered}
$$

Dengan menyelesaikan persamaan diatas, kita dapatkan fungsi transfer sebagai berikut, dimana kecaatan sudut sebagai keluaran dan tegangan jangkar sebagai masukannya.

$$
\frac{\theta(s)}{E_{a}(s)}=\frac{K_{t}}{(J S+b)(L S+R)+K_{t}^{2}}
$$

\section{I.3.2. Sistem Kendali Digital}

Blok diagram yang memperlihatkan suatu sistem kendali digital dapat dilihat pada Gambar 2, (Phillip,1995) . Komputer digital melaksanakan fungsi kompensasi didalam sistem. Antar muka pada masukan komputer adalah suatu pengubah analog ke digital (A/D) yang diperlukan untuk mengubah sinyal galat, yaitu suatu sinyal waktu kontinyu kedalam suatu bentuk linier yang dapat diproses komputer. Antara muka pada keluaran komputer diperlukan untuk mengaktifkan kendalian, yang disebut suatu pengubah digital ke analag (D/A), (Phillip, 1998).

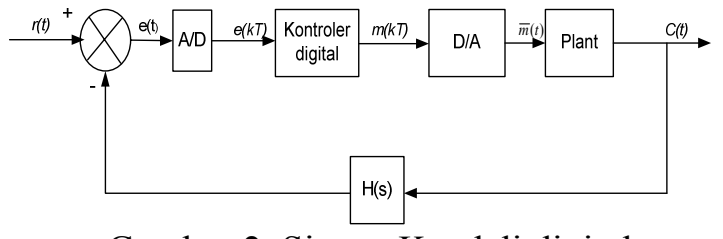

Gambar 2. Sistem Kendali digital (Phillip,1995)

Berdasarkan Gambar 2, pengubah A/D pada masukan pengendali akan mengubah sinyal waktu kontinyu $e(t)$ kesuatu deretan bilangan $e(k T)$, pengendali digital akan mengolah deretan angka $e(k T)$ ini dan menghitung deretan angka keluaran $m(k T)$. Deretan angka $m(k T)$ ini kemudian dikonversikan kesinyal waktu kontinyu $\bar{m}(t)$ melalui pengubah D/A. Pengendali dan pengubah $\mathrm{A} / \mathrm{D}$ dan $\mathrm{D} / \mathrm{A}$ serta kendalian yang berkaitan dapat diberikan dalam bentuk diagram blok seperti terlihat pada Gambar 3 . Berdasarkan Gambar 3 diperoleh,

$$
\begin{gathered}
E(s)=R(s)-G(s) H(s) D^{*}(s) E^{*}(s) \\
C(s)=G(s) D^{*}(s) E^{*}(s)
\end{gathered}
$$

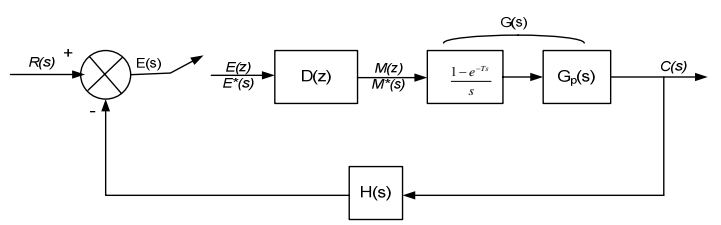

Gambar 3. Sistem Kendali digital dengan Pengubah A/D dan D/A

(Phillip,1995)

Tanda bintang persamaan untuik $E(s)$, dan menyelesaikan $E^{*}(s)$ diperoleh

$$
E *(s)=\frac{R *(s)}{1+D^{*}(s) \bar{G} \bar{H} *(s)}
$$

Transformasi-z dari persamaan untuk $C(s)$ dengan mensubsitusikan $E^{*}(s)$ pada persamaan diatas diberikan oleh

$$
C(z)=\frac{D(z) G(z)}{1+D(z) \bar{G} \bar{H}(z)} R(z)
$$

Maka 


$$
T(z)=\frac{C(z)}{R(z)}=\frac{D(z) G(z)}{1+D(z) \bar{G} \bar{H}(z)}
$$

Persamaan diatas merupakan fungsi transfer closed loop dari sistem kendali digital berdasarkan Gambar 3. Jika pengendali digital yang digunakan adalah PID, dengan $e(t)$ adalah masukan ke alat kontrol PID, keluaran $m(t)$ dari alat kontrol ini diberikan oleh

$$
m(t)=K_{p} e(t)+K_{i} \int_{0}^{t} e(t) d t+K_{p} \frac{d e(t)}{d t}
$$

Algoritma pengendali PID dalam bentuk digital sebagai berikut

atau

$$
M(z)=D(z) E(z)=\left[K_{p}+\frac{K_{i} T z}{z-1}+K_{d} \frac{z-1}{T z}\right] E(z)
$$

$$
\begin{array}{r}
D(z)=\frac{M(z)}{E(z)}= \\
{\left[K_{p}+\frac{K_{i} T}{1-z^{-1}}+K_{d} \frac{1-z^{-1}}{T}\right]}
\end{array}
$$

Pengendali PID digital diperlihatkan pada Gambar 4.

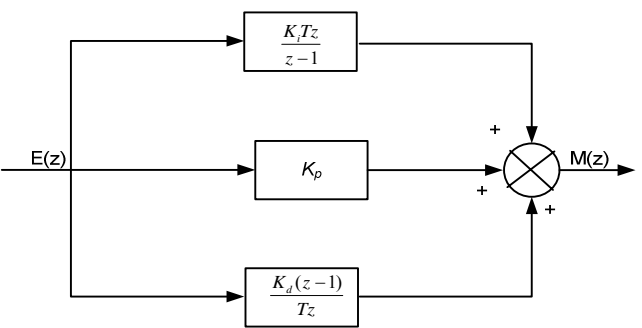

Gambar 4. Pengendali PID digital (Phillip, 1995)

Fungsi transfer pengendali PID dapat ditulis dalam bentuk, (Tang, 1999),

$$
D(z)=\frac{b_{0}+b_{1} z^{-1}+b_{2} z^{-2}+\ldots . .+b_{m} z^{-m}}{1+a_{1} z^{-1}+a^{2} z^{-2}+\ldots . a_{n} z^{-n}}
$$

\section{Dimana}

$$
\begin{aligned}
& b_{0}=K_{p}+K_{i} T+\frac{K_{d}}{T} \\
& b_{1}=-\left(K_{p}+2 \frac{K_{d}}{T}\right) \\
& b_{2}=\frac{K d}{T} \\
& a_{1}=-1 \\
& a_{2}=0
\end{aligned}
$$

dengan

$K_{p}=$ penguatan proporsional

$K_{i}=$ penguatan integarl

$K_{d}=$ penguatan turunan (derivatif)

$\mathrm{T}=$ perioda pencuplikan

$\mathrm{D}(\mathrm{z})=$ Fungsi transfer pengendali PID

Pengendali PID memiliki fungsi alih sebagi berikut, (Phillips, 1995, Tang, 1999):

$$
D(z)=K_{p}+K_{I} \frac{T}{2}\left[\frac{z+1}{z-1}\right]+K_{D}\left[\frac{z-1}{T z}\right]
$$

Tiga parameter pengendali, $K_{p}, K_{i}$ dan $K_{d}$ ditentukan dengan proses perancangan.

\section{I.3.3. Pengendali Proposional}

Elemen pertama dari kendali PID yang akan dikembangkan yaitu kendali proporsional. Dinamika dari pengendali proporsional adalah memberikan suatu nilai dalam bentuk konstanta yang besarnya dapat diubah-ubah sesuai dengan kebutuhan keluaran sistem yang hendak dicapai. Untuk pengendali proporsional, hubungan antara masukan pengendali $m(t)$ dengan sinyal galat aktuasi $e(t)$ adalah :

$$
m(t)=K_{p} e(t)
$$

Kekurangan pengendali ini adalah terjadinya kesalahan mantap (galat offset) bila ada perubahan beban. Dengan demikian sistem ini harus dapat direset secara manual dan sebaliknya perubahan beban tidak besar. Error steady state dapat dikurangi dengan memperbesar penguatan , akan tetapi penguatan yang terlalu besar akan mengakibatkan semakin besarnya derau dan 
sistem menjadi tidak stabil (Ogata,1997, Rusli, 1997) .

\section{I.3.4. Pengendali Proporsional Plus Integral (PI)}

Kekurangan pengendali proporsional dapat dihilangkan dengan memasukkan elemen pengendali integral. Bentuk persamaan pengendali PI adalah sebagai berikut (Phillips, 1998).

$$
m(t)=K_{p} e(t)+K_{i} \int_{0}^{t} e(t) d t
$$

Sehingga fungsi alihnya dapat ditulis sebagai berikut

$$
\frac{M(z)}{E(z)}=D(z)=K_{p}+K_{I}\left(\frac{z+1}{z-1}\right)
$$

Elemen

$$
\text { pengendali }
$$

integral

mempunyai kelemahan dalam respon dinamik, dimana pengaturan lingkar tertutup berosilasi dengan amplitudo yang mengecil secara perlahan atau bahkan amplitudo yang membesar, biasanya kedua hal ini tidak diinginkan. Beberapa sifat pengendali Proporsional plus Integral, (Ogata,1997):

a. Aksi kendali proporsional cendrung menstabilkan sistem

b. Aksi kendali integral cendrung menghilangkan atau memperkecil galat keadaan tunak dari tanggapan terhadap berbagai masukan

\section{I.3.5. Pengendali Proporsional Plus Derivatif (PD)}

Kendali derivatif selalu digunakan bersama-sama dengan aksi proporsional. Aksi kendali derivatif mendahului kesalahan pengerak, mengawali aksi koreksi dini dan cendrung memperbesar kesatbilan sistem. Bentuk persamaan pengendali PD adalah (Phillips, 1998),

$$
m(t)=K_{p} e(t)+K_{d} \frac{d e(t)}{d t}
$$

Beberapa sifat pengendali PD ini adalah sebagai berikut (Ogata,1997); a. Elemen derivatif dapat menyebabkan efek saturasi pada pengendali dan tidak dapat berdiri sendiri mengingat komponen ini hanya bekerja hanya selama masa transient atau perubahan.

b. Mode derivatif dapat mengatasi perubahan beban seketika.

c. Offset galat tidak dapat dihilangkan, akibat adanya komponen porposional

\section{I.3.6. Desain Kontrol Optimal Kuadratik}

Metode klasik, sistem kontrol mulamula dirancang dan selanjutnya kestabilannya diuji. Sedangkan dalam metode yang akan dibahas ini, kondisi kestabilannya yang pertama dirumuskan, setelah itu sistemnya dirancang dalam keterbatasannya (Ogata,1997). Dengan menggunakan analisa ruang keadaan (state space) maka akan memungkinkan dilakukan sistem kontrol yang optimal terhadap indeks performans yang diberikan. Variabel keadaan suatu sistem dinamik dimaksudkan sebagai himpunan terkecil dari variabel-variabel yang menentukan keadaan sistem dinamik sedemikian rupa sehingga dengan mengetahui variabel ini dapat menentukan secara lengkap perilaku sistem untuk setiap waktu $\mathrm{t} \geq \mathrm{t}_{0}$ dan dengan syarat awal pada $\mathrm{t}=$ $\mathrm{t}_{0}$.Selain itu variabel keadaan tidak perlu merupakan besaran yang secara fisik dapat diukur atau diamati, namun secara praktis sebaiknya dipilih variabel keadaan yang merupakan besaran yang dapat diukur secara mudah karena hukum kontrol optimal akan memerlukan umpan balik semua variabel keadaan dengan matrik pembobotan yang sesuai.

Sistem kontrol yang ditinjau memiliki persamaan sistem :

$$
x(k+1)=G x(k)+H u(k)
$$

Matrik $K$ vector kontrol optimal didifinisikan sebagai

$$
u(k)=-K x(k)
$$

dimana

$$
x(k)=\text { vektor keadaan (n-vektor) }
$$




$$
\begin{aligned}
u(k) & =\text { vektor kontrol (r-vektor) } \\
G & =\text { matriks konstan } n \times n \\
H & =\text { matriks konstan } n \times r \\
K & =\text { penguatan } r \times n
\end{aligned}
$$

Untuk merancang sistem kontrol yang selalu stabil, sistem kontrol yang dirancang berdasarkan pada meminimumkan indek kinerja kuadratik dengan persamaan (Lewis, 1992, dan Ogata,1994),

$\left.J=\frac{1}{2} x^{\prime}(k) S x(k)+\frac{1}{2} \sum_{k=0}^{N-1} x^{\prime}(k) Q x(k)+u^{\prime}(k) R u(k)\right]$

Pertimbangkan masalah kontrol optimal kuadratik untuk proses yang berlangsung secara kontinu tanpa batas, atau $\mathrm{N}=\infty$, solusi persamaan kontrol optimal menjadi solusi persamaan steady state, maka indek kinerja kuadratik yang diminimumkan dapat dimodifikasi sebagai

$$
J=\frac{1}{2} \sum_{k=0}^{\infty 1}\left[x^{\prime}(k) Q x(k)+u^{\prime}(k) R u(k)\right]
$$

Dan persamaaan Riccati ditulis

$$
\begin{aligned}
P & =Q+G^{\prime} P\left(I+H R^{-1} H^{\prime} P\right)^{-1} G \\
& =Q+G^{\prime} P\left(P^{-1}+H R^{-1} H^{\prime}\right)^{-1} G
\end{aligned}
$$

Dimana

$Q=$ matriks bobot definitif positif atau matrik simetrik real $(n \times n)$

$R \quad=$ matriks bobot definitif positif atau matrik simetrik real $(r \times r)$

$S=$ matriks bobot definitif positif atau matrik simetrik real $(n \times n)$

$P(k)=$ solusi persamaan Ricccati(matriks definitif positif)

Untuk menentukan matrik penguat umpan balik $K$ digunakan persamaan

$$
K=\left(R+H^{\prime} P H\right)^{-1} H^{\prime} P G
$$

Dengan mensubsitusikan persamaan

pada persamaan (32), maka vektor kontrol optimal dapat ditulis sebagai

$$
u(k)=-\left(R+H^{\prime} P H\right)^{-1} H^{\prime} P G x(k)
$$

Subsitusikan persamaan (38) dalam persamaan (31) diperoleh sistem regulator optimal dengan persamaan

$$
\begin{aligned}
& x(k+1)=\left[G-H\left(R+H^{\prime} P H\right)^{-1} H^{\prime} P G\right] x(k) \\
& =\left(I+H R^{-1} H^{\prime} P\right)^{-1} G x(k)
\end{aligned}
$$

Nilai minimum indek kinerja $J$ diberikan oleh persamaan

$$
J_{\min }=1 / 2 x^{\prime}(0) P(0) x(0)
$$

Dimana Q dan R dipilih positif definitif agar menghasilkan sistem yang selalu stabil.

Realisasi kontrol optimal dalam keadaan steady state membutuhkan solusi persamaan Riccati dalam keadaan steady state. Persamaan riccati nonsteady state diberikan oleh

$P(k)=Q+G P(k+1) G-G P(k+1) H R+H P(k+1) H]^{-1} H P(k+1) G$

atau

\section{$P(k+1)=Q+G P(k) G-G P(k) H[R+H P(k) H]^{-1} H P(k) G$}

Blok diagram sistem kendali optimal dengan metode LQR seperti gambar dibawah ini:

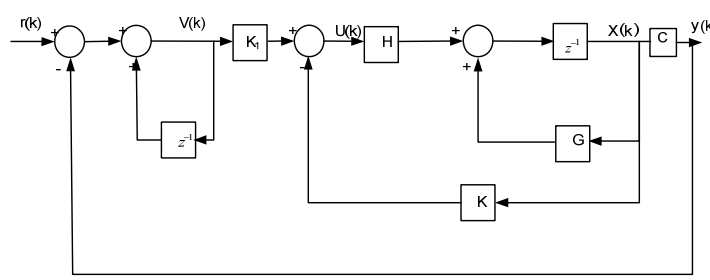

$$
\begin{gathered}
\text { Gambar 5. Blok diagram sistem kendali } \\
\text { dengan metode LQR }
\end{gathered}
$$

\section{(Ogata, 1994)}

Untuk menentukan unit-step sistem digunakan blok diagram seperti gambar 5, input $\mathrm{r}(\mathrm{k})$ diasumsikan unit-step respon.

Persamaan sistem diberikan oleh :

$$
\begin{aligned}
& \mathrm{x}(\mathrm{k}+1)=\mathrm{Gx}(\mathrm{k})+\mathrm{Hu}(\mathrm{k}) \\
& \mathrm{y}(\mathrm{k})=\mathrm{Cx}(\mathrm{k})
\end{aligned}
$$

Persamaan untuk integrator dalam bentuk

$$
\mathrm{v}(\mathrm{k})=\mathrm{v}(\mathrm{k}-1)+\mathrm{r}(\mathrm{k})-\mathrm{y}(\mathrm{k})
$$


sehingga

$$
\mathrm{u}(\mathrm{k})=-\mathrm{Kx}(\mathrm{k})+\mathrm{K}_{1} \mathrm{v}(\mathrm{k})
$$

Dengan mensubsitusikan persamaan (46) pada persamaan (43) diperoleh:

$\mathrm{x}(\mathrm{k}+1)=\mathrm{Gx}(\mathrm{k})+\mathrm{H}\left[-\mathrm{Kx}(\mathrm{k})+\mathrm{K}_{1} \mathrm{v}(\mathrm{k})\right](47)$

$\mathrm{x}(\mathrm{k}+1)=(\mathrm{G}-\mathrm{HK}) \mathrm{x}(\mathrm{k})+\mathrm{HK}_{I} \mathrm{v}(\mathrm{k})$

dimana :

$$
\mathrm{K}=\left[\begin{array}{lll}
\mathrm{k}_{1} & \mathrm{k}_{2} & \mathrm{k}_{3}
\end{array}\right]
$$

Karena

$\mathrm{v}(\mathrm{k}+1)=\mathrm{v}(\mathrm{k})+\mathrm{r}(\mathrm{k}+1)-\mathrm{y}(\mathrm{k}+1)$

dimana

$$
\mathrm{y}(\mathrm{k})=\text { keluaran sistem }
$$

\section{I.4. Manfaat Penelitian}

Manfaat yang diharapkan dari penelitian ini adalah sebagai bahan masukan atau pertimbangan untuk implementasi sistem kontrol posisi motor DC agar dihasilkan sistem kontrol yang stabil dan optimal akibat perubahan beban.

\section{Metode Penelitian}

Penelitian ini menggunakan metode PID dan LQR untuk mengatur posisi pada motor DC servo HITEC HS-422. Tahap penelitian terdiri dari penentuan koefisienkoefisien kontroler PID dan matrik bobot untuk metode LQR. Kriteria penelitian yang ingin dicapai adalah kestabilan sistem yang berhubungan dengan kecepatan respon sistem dan persentase overshoot dengan melakukan perubahan terhadap posisi motor DC tanpa gangguan dan dengan adanya gangguan. Tahapan penelitian ini terdiri dari:

1. Studi literatur mengenai sistem kendali posisi motor DC menggunakan metode PID dan LQR

2. Penurunan persamaan model matematis plant yang akan dikontrol (motor dc servo) dalam bentuk persamaan fungsi alih dan state space .
3. Mengumpulkan data parameter motor DC servo HITEC HS-422 melalui data sheet motor DC dan hasil proses identifikasi.

4. melakukan pengujian kontroler untuk mengatur posisi model motor DC servo HITEC HS-422 menggunakan metode PID dan LQR dengan adanya gangguan dan tanpa gangguan.

5. Analisa terhadap hasil pengujian.

\section{Hasil Dan Pembahasan}

Motor DC servo yang digunakan pada penelitian ini adalah motor Deluxe HITEC HS-422 dengan parameter motor sebagai berikut:

1. Koefisien viskos rotor dan beban, $\mathrm{B}=0.008$

2. Momen inersia rotor dan beban, $\mathrm{J}=5.7 \mathrm{e}-007 \mathrm{Kg} / \mathrm{m}^{2}$

3. Konstanta torsi motor, $\mathrm{Km}=0.0134 \mathrm{Nm} / \mathrm{A}$

4. Induktansi jangkar $\mathrm{La}=6.5 \mathrm{e}-005 \mathrm{H}$

5. Tahanan jangkar $\mathrm{Ra}=1.9 \mathrm{Ohm}$ langkah pertama yang dilakukan adalah pengujian lup tertutup plant motor DC tanpa kontroler dan diamati respon stepnya, kemudian dilanjukan dengan pengujian kontroler PID untuk mengontrol posisi motor DC pada perubahan posisi tanpa gangguan dan dengan adanya gangguan .

Gambar berikut memperlihatkan repon step lup tertutup sistem tanpa adanya kontroler.

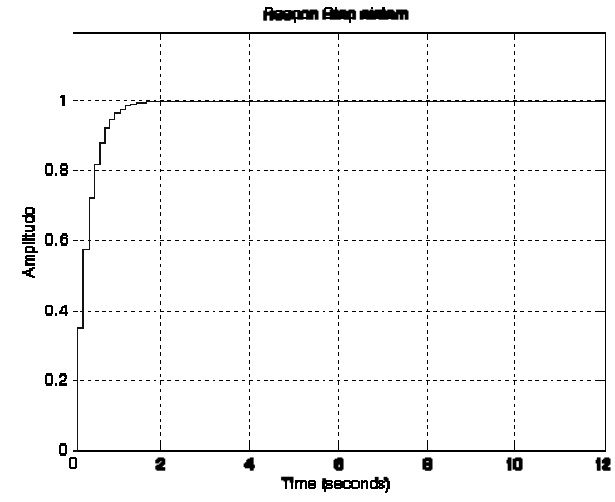

Gambar 6. Respon step lup tertutup plant tanpa kontroler 
Hasil respon step lup tertutup plant tanpa kontroler diperoleh sistem menuju kestabilan dengan waktu setling sekita 1.8 detik.

Pengujian pengaruh pembebanan pada kontroler PID diginakan model pada Gambar 7 di bawah ini.

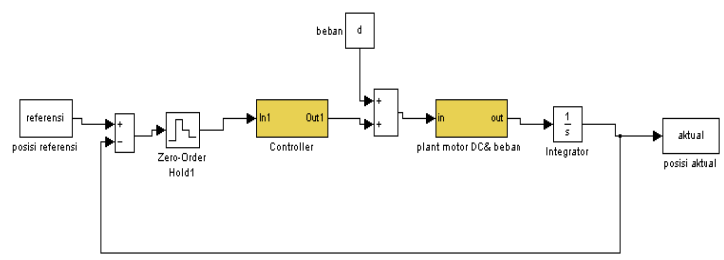

Gambar 7. Diagram kontrol untuk sebuah motor DC

\section{III.1. Kontrol Posisi Menggunakan Kontroler PID Dan LQR Tanpa Gangguan}

Setelah respon step lup tertutup plant tanpa kontroler diperoleh, dilakukan penelitian untuk pengontrolan posisi keluaran motor DC sesuai dengan referensi posisi masukan yang diberikan dan diharapkan sistem akan selalu stabil setiap perubahan posisi tanpa gangguan.

Gambar 8 dan 9 berturut-turut memperlihatkan hasil pengujian kontroler PID untuk mengontrol posisi motor DC. Pada pengujiani ini diasumsikan sudut poros motor pada saat start adalah berada pada posisi $0^{0}$, kemudian motor harus menggerakkan beban menuju posisi $11^{\circ}$ atau 0.2 radian dan $60^{\circ}$ atau 1.047 radian. Parameter kontrol yang dipilih dalam pengujian diatas untuk posisi 0.2 radian dan 1.047 radian masing-masing adalah :

$$
\begin{aligned}
& \mathrm{Kp}=2.0 \\
& \mathrm{Ki}=0.001 \\
& \mathrm{Kd}=0.00001
\end{aligned}
$$

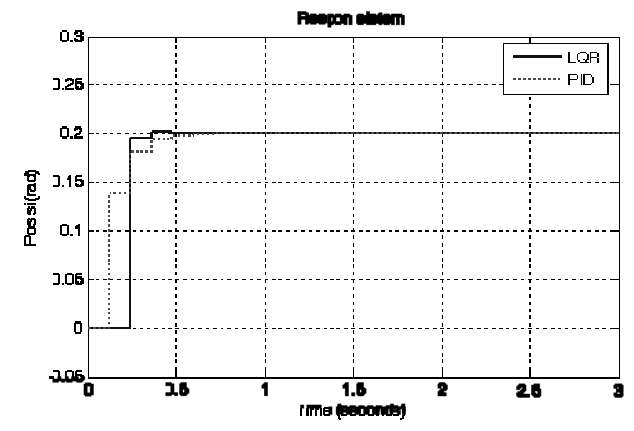

Gambar 8. Respon lup tertutup sistem dengan kontroler PID dan LQR tanpa gangguan untuk posisi $0.2 \mathrm{rad}$

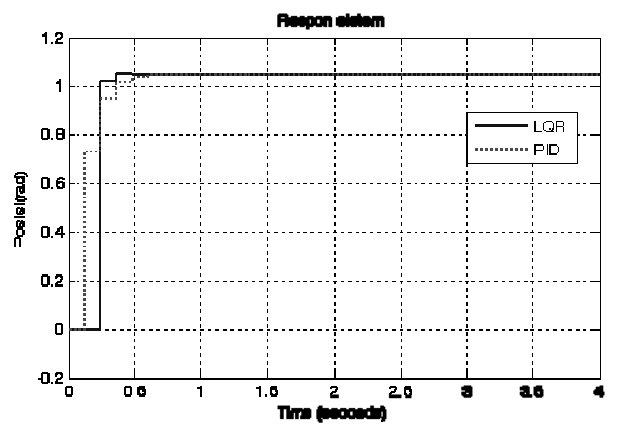

Gambar 9. Respon lup tertutup sistem dengan kontroler PID dan LQR tanpa gangguan untuk posisi $1.047 \mathrm{rad}$

Dari Gambar 8 dan 9 dapat dilihat respon sistem dengan menggunakan kontroler PID cukup baik, waktu yang dibutuhkan untuk mencapai sistem yang stabil dengan menggunakan kontroler PID masing - masing berada pada $\mathrm{t}=0.72$ dan 0.6 detik dengan persentase Overshoot 0.054 $\%$. Dari gambar di atas juga terlihat hasil pengujian kontroler LQR untuk mengontrol posisi motor DC untuk posisi $11^{0}$ atau 0.2 radian dan $60^{\circ}$ atau 1.047 radian. Matrik bobot yang dipilih dalam pengujian untuk posisi 0.2 radian dan 1.047 radian adalah :

$\mathrm{R}=0.001$

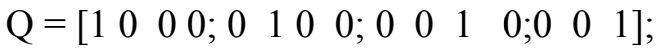

Waktu yang dibutuhkan untuk mencapai sistem yang stabil dengan menggunakan LQR berada pada $\mathrm{t}=0.48$ detik, lebih cepat dibandingkan menggunakan PID dengan persentase Overshoot $0.66 \%$ untuk posisi $11^{0}$ dan $0.59 \%$ untuk posisi $60^{\circ}$.

\subsection{Kontrol Posisi Menggunakan Kontroler PID Dan LQR Dengan Adanya Gangguan}

Pengujian pengaruh gangguan atau perubahan beban terhadap kestabilan sistem dalam mengontrol posisi keluaran motor DC sesuai dengan referensi posisi masukan yang diberikan, dilakukan dengan menambah 
beban torsi pada motor. Beban yang diberikan mulai dari $0,0,1 \mathrm{Nm}, 0.3 \mathrm{Nm}$ dan $0.5 \mathrm{Nm}$.

Dalam pengujian ini diasumsikan sudut poros motor pada saat start adalah berada pada posisi $0^{0}$, kemudian motor harus menggerakkan beban menuju posisi $11^{0}$ atau 0.2 radian dan $60^{\circ}$ atau 1.047 radian. Hasil pengujian pengaruh pembebanan pada kontroler PID dan LQR diperlihatkan pada gambar berikut.

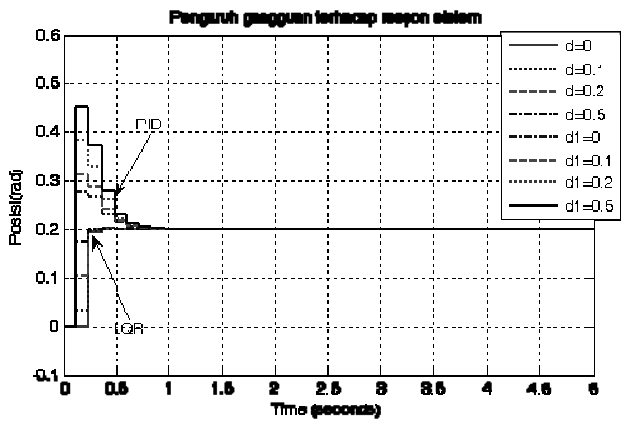

Gambar 10. Respon lup tertutup sistem dengan kontroler PID dan LQR dengan gangguan untuk posisi $0.2 \mathrm{rad}$

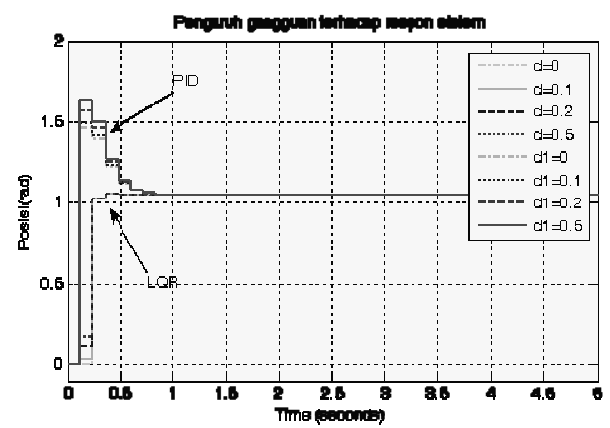

Gambar 11 Respon lup tertutup sistem dengan kontroler PID dan LQR dengan gangguan untuk posisi $1.047 \mathrm{rad}$

Gambar 10 dan 11 memperlihatkan hasil pengujian yang menujukkan respon kontroler PID dan LQR terhadap gangguan (perubahan beban pada poros motor). Nampak bahwa kontroler PID mampu menjaga konvergensi atas perubahan beban, namun demikian makin besar beban maka makin tinggi pula overshootnya, sedangkan waktu yang dibutuhkan sistem untuk mencapai kestabilan berturut-turut 0.86 detik dan 1.0 detik. Nilai persentase overshoot untuk posisi $11^{0}$ berturut-turut dari $29.3 \%, 48,7 \%$ dan $69,4 \%$, untuk pembebanan torsi $0.1 \mathrm{Nm}, 0.3$ $\mathrm{Nm}$ dan $0.5 \mathrm{Nm}$, sedangakan posisi $60^{\circ}$ persentase oveshootnya untuk masingmasing gangguan torsi sebesar $22.1 \%, 25,5 \%$ dan $28.9 \%$. Parameter kontrol yang dipilih dalam pengujian diatas untuk posisi 0.2 radian dan 1.047 radian masing-masing adalah :

$$
\begin{aligned}
& \mathrm{Kp}_{1}=3.3 \\
& \mathrm{Ki}_{1}=3.5 \\
& \mathrm{Kd}_{1}=0.00001 ; \\
& \mathrm{Kp}=3.0 \\
& \mathrm{Ki}=3.5 \\
& \mathrm{Kd}=0.00001 ;
\end{aligned}
$$

Pada Gambar 10 dan 11 nampak bahwa kontroler LQR dalam kasus kontrol posisi ini responsif terhadap perubahan beban, terlihat kontroler LQR mampu menjaga konvergensi atas perubahan beban tanpa peningkatkan berarti pada overshootnya. Matrik bobot yang dipilih dalam pengujian untuk posisi $11^{0}$ dan $60^{\circ}$ adalah:

$$
\begin{aligned}
& \mathrm{R}=0.001
\end{aligned}
$$

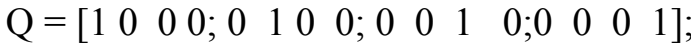

Nilai persentase overshoot berturut-turut $0,384 \%$ dan $0,599 \%$ untuk posisi $11^{0}$ dan $60^{\circ}$, sedangkan waktu yang dibutuhkan sistem untuk mencapai kestabilan adalah sekitar 0.48 detik, lebih cepat dibandingkan menggunakan PID.

\section{Kesimpulan}

Berdasarkan penelitian kontrol posisi menggunakan kontroler PID dan LQR dengan adanya gangguan atau tanpa adanya gangguan dapat disimpulkan sebagai berikut:

a. Metode LQR untuk mengontrol posisi motor DC mempunyai kestabilan yang kokoh dan ketelitian yang tinggi hal ini terbukti walaupun sinyal kontrol sudah mengalami gangguan, output sistem masih stabil dan waktu yang dibutuhkan sistem untuk mecapai kestabilan dengan adanya gangguan mendekati waktu yang 
dibutuhkan sistem tanpa adanya Rusli, Mohammad: 1997, Sistem Kontrol gangguan. kedua, Malang: Teknik Elektro -

b. Pada penelitian posisi tanpa adanya Universitas Brawijaya gangguan atau dengan adanya gangguan, Tang, jianxin, R. Chassaing, 1999, PID respon sistem dengan menggunakan Controller Using the TMS320C31 DSK kontroler LQR lebih cepat mencapai sistem yang stabil dibandingkan for Riel Time DC motor Speed and Position Control, North Dartmouth.

c. Dari penelitian menggunakan kontrol PID untuk sistem kontrol posisi dengan adanya ganguan, sistem masih mampu menjaga konvergensi atas perubahan beban, namun perubahan beban atau gangguan yang besar menyebabkan oveshootnya makin tinggi pula.

d. Pemakaian kontroler LQR dapat dipertimbangkan untuk sistem dengan adanya perubahan beban atau gangguan.

\section{Daftar Pustaka}

Dorf, Rc. And Bishop, RH, 1995, Moderen Control System, $7^{\text {Th }}$ Edition, Addison Wesley Publishing Company.

Garg, Aditya, 2001, Adaptif and Optimal Tracking Control of Electromechanical Servosystem, Thesis.

Gopal, M, 2004, Digital Control and State Variable Methods, $2^{\text {nd }}$ Edition, McGraw-Hill Publishing Company Limited.

Hasan, 1998, Aplikasi Sistem Kontrol Optimal dalam Reaktor Nuklir, Elektor Indonesia, Edisi ke Dua Belas

Lewis,L. Frank, 1992, Applied Optimal Control \& Estimation, Prentice Hall International. Inc.

Ogata, K, 1997, Moderen Control Engineering, $3^{\text {rd }}$ Edition, Prentice Hall International. Inc.

Phillips, L. Charles, 1995, Digital control System, $3^{\text {rd }}$ Edition, Prentice Hall International. Inc.

Phillips, L. Charles and R.J Widodo, 1998 , Sistem Kontrol Lanjut. $3^{\text {rd }}$ Edition, Eedisi Bahasa Indonesia, PT Prenhallindo, Jakarta. 